\title{
Personating leadership: Shakespeare's Henry $V$ and performative negotiation
}

\author{
Kristin M.S. Bezio \\ Assistant Professor of Leadership Studies, Jepson School of Leadership Studies, University of \\ Richmond, USA
}

This essay examines early modern notions of ideal and problematic leadership through the lens of Shakespeare's King Henry $V$. The piece argues that critical depictions of Henry as either charismatic or Machiavellian are reductive; Henry's success as a monarch derives from his ability to balance necessary authority with what I term 'performative negotiation.' In this model, Henry's publicly constructed persona serves as a means of 'negotiating' his sovereignty with his subjects, but also acts as an exemplum for the present and future monarchs of England.

Keywords: Elizabeth I, Henry V, kingship, leadership, literature, performance, Shakespeare, succession crisis, theater

Narratives of both leaders and leadership appear frequently in works of literature, from children's stories to the great works of the Western literary canon (Shushok and Moore 2010; Nelhs 2012). Since 'leadership is rooted in storytelling' (Nehls 2012, p. 64), it should be natural for leadership scholars to turn to literature for examples of and arguments about leadership. William Shakespeare's Henry $V$, based on the historical successes of the fifteenth-century English king, is deeply concerned with the complex nature of leadership. Particularly when considered in relation to its original context, Henry $V$ indicates the complicated and often vexed relationship between Shakespeare's audience and their Elizabethan monarch. In 1599, the date of the play's inaugural performance, the presentation of monarchy on the public stage was an act of political speech, subject to critique from authority even as it was itself able to (cautiously) participate in contemporary sociopolitical discussions of the nature - and appropriate limitations - of monarchy (Axton 1977). By examining Henry $V$ as an allegorical representation of English monarchy, we are shown a picture of sovereignty that is simultaneously idealized and fallible.

This paradoxical interpretation of Shakespeare's most successful king is reflected by the fact that despite Henry's obvious position as a military and political leader, there is still some scholarly debate over whether his reputation as 'the mirror of all Christian kings' (II.0.6) ${ }^{1}$ is the product of effective or manipulative leadership (Rabkin 1977; Pye 1990; Deats 2004). The crux of the contention is that Henry is a consummate performer who appears in multiple guises: a captain concerned about the wellbeing of his soldiers, an actor who assumes the guise of a commoner, and a king who threatens the city of Harfleur with atrocity, orders the execution of the French prisoners of war, and nevertheless still spurs his men to great victory at Agincourt.

1. All Henry $V$ citations are from the 1995 edition shown in the reference list. 
Within the play, the adoption of these multiple roles permits Henry to negotiate the responsibilities and expectations of sovereign leadership; on stage, these multiple 'performances' complicate Shakespeare's representation of ostensibly 'ideal' sovereignty, and reflect contemporaneous debates on the ideologies of absolutism and limited monarchy.

In Shakespeare's play, Henry appears as the embodiment - the 'personation' (Gurr 1980, p. 98), to borrow an early modern term - of leadership transferred by the player through both discursive and extra-linguistic (bodily) means onto the theatrical stage. Wills (1994) downplays the importance of both authors and actors in leadership terms, suggesting that 'An actor is not, as such, a leader. The appreciation of an audience is not motion toward some goal shared with the actor' (p. 30). Yet the early modern public stage was as much a political forum as it was a locus for entertainment. In 1586, in her address to Parliament on the 12th of November, Elizabeth publicly acknowledged the intimate link between theatricality and the enaction of sovereignty:

for we princes, I tell you, are set on stages in the sight and view of all the world duly observed. The eyes of many behold our actions; a spot is soon spied in our garments; a blemish quickly noted in our doings. It behooveth us therefore to be careful that our proceedings be just and honorable. (Marcus et al. 2000, p. 194)

The ubiquitousness of the overlap between the political and theatrical in early modern London led to the censorship of any play depicting a living monarch, out of concern for drama's ability to influence the populace into revolt.

Perhaps the best example of this relationship is the 1601 staging of another of Shakespeare's histories, Richard II (1595/6). Montrose (1996) notes that 'On the afternoon of Saturday, 7 February 1601, Shakespeare's company performed at the Globe a "play of the deposyng and kyllyng of Kyng Rychard the second" that was presumably although not incontrovertibly - Shakespeare's Tragedie of King Richard the second' (p. 52; State Papers Domestic, Elizabeth 278.85).

The intent of this performance was to incite popular support for the rebellion of Robert Devereaux, Earl of Essex, against Elizabeth. ${ }^{2}$ Although it failed in its goal of motivating the populace, the fact that a play was used in the attempt illustrates the correlation between the theatrical and the political in the minds of early moderns. Montrose (1996) explains:

To the Elizabethan government, the spectacular failure of Essex in his attempt to arouse the Queen's subjects in the streets of London may have suggested that the players' performance of their playwright's play was probably innocent of seditious intent. Such a response on the part of the Privy Council would have implied not that the theatre was politically ineffectual but, on the contrary, that it was powerful indeed. (p. 54)

Elizabeth herself is said to have confirmed the influence of the theatrical over the political in a comment to William Lambarde immediately following the incident, proclaiming, 'I am Richard the Second. Know ye not that?' (Axton 1977, p. 2). By thus confirming the allegorical significance of a staged monarch to the direct criticism of and even rebellion against the enthroned monarch, we see the importance of such representations to early moderns. Within this complex context, the player's role as leader is that of transmission vector for the author; through his depiction of Henry in Henry V, then,

2. During Essex's trial, both Sir Gelly Meyricke, one of Essex's supporters, and Augustine Phillips, an actor in the Lord Chamberlain's Men, testified that the play had been commissioned with the intent of inciting the audience to rebellion (Craig 1912, p. xii). 
Shakespeare interrogates the extant political ideologies of sovereignty, specifically the competing claims of absolutism and participatory limited monarchy.

English monarchical tradition, predating the 1066 Norman Conquest and extending up to the late fifteenth century, was one of participatory limited rather than absolute monarchy (Baumer 1966, p. 5; Birdsall 1967, p. 37; Nenner 1977, p. 33; Eccleshall 1978 , p. 2; Starkey 2006, p. 19). Participatory limited monarchy was not - as has been suggested by some critics - a step toward democratization; rather, it was, as both medieval and early moderns understood it, still a monarchy, albeit one that acknowledged the rights of subjects, both noble and common alike. It wasn't until the accession of Henry VII (Henry Tudor) in 1485 that absolutism gained a significant foothold in English political ideology (Baumer 1966, pp. 6 and 21; Myers 1982, pp. 299 and 323; Starkey 1986, pp. 15-16). ${ }^{3}$ Henry VII's assertions of the 'disposition of God' and 'manifest, certain and authentic revelation' of sovereign authority remained largely unquestioned by Tudor subjects until the Henrician Reformation in the sixteenth century (Smith 1996, p. 93). Under both Mary and Elizabeth, the debate escalated as political tracts and poems sought to argue for the legitimacy of deposition and tyrannicide, yet both queens continued to press the ideology of divine authorization (Montrose 2006). Elizabeth repeatedly and publicly reminded both Parliament and subjects that 'princes be set in their seat by God's appointing,' 'God hath made kings,' and 'God hath made me to be a Queen,' although with the caveat that 'this I count the glory of my crown, that I have reigned with your loves' (Marcus et al. 2000, pp. 54, 268, and 337). By 1599, the discourse of Tudor absolutism was well-established, although in practice monarchical authority remained limited by both Parliament and the Privy Council (Bezio 2013). The result was the continued public discussion held in speeches, in print, and on stage - of sovereignty (Sommerville 1999).

This conflict is reflected in Shakespeare's problematic depiction of Henry V, and echoed in later interpretations of both his character and the play as a whole. In Henry $V$, Henry's leadership is rooted in contradictions that have long vexed literary scholarship, but have been largely absent from treatments of the play in leadership studies. Leadership scholars characterize Henry as an icon of rhetorical, military, sovereign, and even (sometimes) proto-democratic leadership, but they are preoccupied with Henry as a positive figure of rhetorical skill, personal accountability, self-confidence, and affinity with the common man (McCombs 1992; Discorfano 2003). Even when leadership scholars acknowledge Henry's paradoxical nature, they tend to efface problematic behavior with the caveat that Shakespeare's good kings, 'like Hal, learn from their pasts' (Cronin and Genovese 2012, p. 113), characterizing Henry as a leader who 'knows himself, knows his world, knows how to appeal to people, and knows politics. He is prepared to govern' (ibid., p. 113). But this polished version of Henry does an injustice to Shakespeare's awareness of the intricacies of rule and leadership. Interestingly, much critical work in literary studies demonstrates an equally problematic desire to paint Henry as a Machiavellian ruler whose primary interest is in expanding and maintaining his power, even at the expense of his nation and his humanity

3. Although there had been attempts by earlier monarchs to enforce absolute rule, the barons (and, later, Parliament) always refused to acknowledge such authority, and the resulting clashes inevitably produced legislation strengthening the rights of subjects and limiting those of the king. The earliest recorded such document, known as the 'Anglo-Saxon Magna Carta,' is dated 1014 in response to Æthelred's attempts to curtail baronial power; the most famous, of course, is Magna Carta itself, a 'restorationist act, seeking to bind the King in the standard medieval ways' (Elshtain 2008, p. 66). 
(Hazlitt 1920; Rackin 1990; McEachern 1994; Parolin 2009; Pittock 2009). If Henry is not as straightforward a good leader as has been argued among leadership scholars, neither is he as devious as many literary scholars purport. Rather, each field seems to have focused on only one aspect of sovereign leadership as Shakespeare has embodied it in Henry: leadership studies on the external, public figure Henry wishes to present; literary studies on the internal conflicts through and over which Henry must triumph in order to present his victorious façade. Shakespeare wants his audience to recognize both.

Part of the problem with Henry arises from the uncertainty of his legitimacy. On the one hand, he inherited the throne from his father, Henry IV, by means of primogeniture. On the other, because of his father's usurpation of Richard II's throne (staged in Richard II), Henry has a tenuous claim for traditional leadership, at best. Shakespeare focuses on this illegitimacy in Henry's private remarks before the battle of Agincourt:

HENRY V Not today, O Lord,

$\mathrm{O}$ not today, think not upon the fault

My father made in compassing the crown. (IV.i.289-291)

In these lines, Henry reminds Shakespeare's audience of what they have already seen in a previous play: the deposition and murder of Richard II, whose death haunted Henry IV in the form of rebellion and guilt, and whose body Henry V reburied in Westminster Abbey in order to atone for his father's sins (Strohm 1996, p. 88). Shakespeare's audience would also have been familiar with the sequence known as the First Tetralogy (1 Henry VI, 2 Henry VI, 3 Henry VI, and Richard III, dated 1590-1593), which chronicles the events following Henry V's death, including the Wars of the Roses and the crowning of Henry VII. These earlier plays blame the Lancastrians for the disruption of Yorkist lineage, resolving only in the unification of the two houses with Henry Tudor's marriage to Elizabeth of York. In refusing to ignore the problematic nature of Henry's claims of traditionalism, Shakespeare requires his audience to look beyond royal blood for legitimacy. For an early modern audience facing the end of a dynastic era, the possibility of finding effective leadership external to traditionalist claims was a hopeful one. However, this outlook also necessitated an ideological shift away from the doctrinal claims of absolutism cultivated and perpetuated by the Tudors (Nenner 1977).

By 1599, Elizabeth I had been on the English throne for 4 decades - many subjects (including Shakespeare) had known no other monarch - and refused to name an heir. The Queen was over 65 years of age in a time when the average adult lifespan was in the $40 \mathrm{~s}$, and the nation faced potential civil war should the succession remain unsettled at the time of her death (Shapiro 2005, p. xv). There were several possible heirs to the throne, including James VI of Scotland, the five female descendants of Henry VIII's sister Mary, Arabella Stuart, the Spanish Infanta, and the Earl of Essex. Of these, most were not serious contenders, although the fears of invasion from both France and Spain produced a great deal of English anxiety at the close of the sixteenth century. Although Henry VIII's will indicated a preference for the Grey line (from his sister Mary) over the Stuart (from his sister Margaret), the Stuarts seemed to be the preferred inheritors (and not simply because of our hindsight knowledge that James ultimately acceded to the English throne). But despite friendly correspondence with James and pressure from Parliament and the Privy Council, Elizabeth refused to designate an heir, producing speculation and fears of both international and civil conflict (Bezio 2013).

By the composition of Henry $V$, it was clear to everyone that primogeniture would be unable to provide the next monarch, and the discussion of sovereignty intensified as 
speculation (and suggestion) increased. While the populace had no control or input, pamphleteers - like the Catholic Robert Parsons - advocated for particular candidates and attempted to reassert traditional claims of limited participatory monarchy, perhaps as a preemptive warning to potential claimants that the English nation would not tolerate tyranny or exploitation. Up to this point, Shakespeare's history plays, too, seemed to advocate caution for potential future monarchs through negative exempla such as John or Richard III. Henry V, however, distinguishes itself from Shakespeare's other histories by depicting a successful king. Interestingly, Henry $V$ also does not conform to the doctrinal absolutism or claims of divine endowment being disseminated by Elizabeth, encouraged by official sermons, and published by the leading contender for the English throne. ${ }^{4}$ The political alternative to failed primogeniture we find in Henry V is leadership based upon performance, a concept that echoes Elizabeth's public recognition of her own role as an actor, while also claiming political influence for the medium of theater itself.

In fact, the primary purpose of the opening Chorus in Henry $V$ is to highlight the need, on the part of both the actors and 'Henry,' for the audience to accept the image he personates:

CHORUS Suppose within the girdle of these walls

Are now confined two mighty monarchies,

Whose high upreared and abutting fronts

The perilous narrow ocean parts asunder.

Piece out our imperfections with your thoughts.

Into a thousand parts divine one man

And make imaginary puissance.

Think, when we talk of horses, that you see them

Printing their proud hoofs i'th' receiving earth.

For 'tis your thoughts that now must deck our kings. (Prologue.19-28)

The Chorus entreats the audience to supplement the deficiencies of the theatrical genre with their imaginations. Because the play's setting cannot be represented realistically on the stage, the audience's willingness to participate imaginatively becomes crucial to theatrical illusion (Weimann 1978). The Choric apology of inadequacy caters not only to dramatic convention, but also this paradigm of imaginative participation:

CHORUS pardon, gentles all,

The flat unraised spirits that hath dared

On this unworthy scaffold to bring forth

So great an object. (Prologue.8-11)

The audience must be willing to both engage with and accept the fiction being offered to them on the 'unworthy scaffold' of the Globe's stage.

Within this description, the Globe Theatre becomes a microcosm not only for France and England, but, as its name implies, the world. And by extension, all that is contained within it - stage, players, and even audience - become imaginatively identified with macrocosmic corollaries outside the theatrical confines of the playhouse. This conception - known as the theatrum mundi, or world-theater - was reflected in the physical as well as ideological space of the theaters themselves, and was

4. James's two treatises, The Trew Law of Free Monarchies (1598) and Basilikon Doron (1599) were published and disseminated in Scotland, although he would have them reprinted following his accession to the English throne in 1603 (Mcllwain 1918). 
widespread throughout Europe and England by the late sixteenth century (Bernheimer 1956). The canopy overhanging the stage was known as the Heavens, and the understage space accessible via trapdoor, Hell, while the scaffolded stage itself stood in for the mortal ground (Hawkins 1966). The metaphor was not limited to space; as Bernheimer (1956) explains, 'the path was prepared by corresponding doctrines about the nature of theatrical audiences' (p. 225), a point reinforced by Cohn's (1967) definition: 'The theatrum mundi topos differs from the scena vitae [life-scene] by its inclusion of an audience. Though both topoi incorporate world-stage and man-actor imagery, theatrum mundi reaches out to embrace an extramundane audience' (p. 28). The presumption of audience inclusion in the theatrum mundi is that they must have a corellational role in the macrocosmic world to that which they occupy in the microcosm of the theater. ${ }^{5}$

In the microcosm created by Henry $V$, the audience - in part because they already conform to this demographic - spectates the doings of both the great and the lowly, acting as the throng of subjects of both England and France. And if the audience becomes the populace within the play, then their naturally analogous role beyond the theater's walls is also that of populace, the subjects of the English nation allegorized by Henry $V$. Through both imaginative participation and the invocation of the theatrum mundi, Shakespeare uses Henry $V$ to engage in contemporary debates about leadership by presenting his audience with Henry as a problematic - both positive and negative - representation of the national anxiety over the question of Elizabethan succession.

In the audience's criticism or approval of the play - 'your humble patience pray, / Gently to hear, kindly to judge our play' (Prologue.33-34) - we find yet another correlation to the external political world. The interplay of performance and audience acceptance or rejection suggests a means of 'negotiating the terms, rather than the fact, of their subordination' (Braddick and Walter 2001, p. 42) within the early modern sociopolitical hierarchy. This concept - which I term 'performative negotiation' relies upon physiological and verbal cues to transmit an image of leadership which the subjects-as-audience choose to accept or reject. Braddick and Walter (2001) discuss the early modern relationship of leadership role to audience acceptance explicitly in terms of 'negotiation':

Lordship, gentility and magistracy were all social roles demanding active representation of the power the role claimed. To assume a social role is necessarily to enter into a negotiation with the audience or audiences for the enactment of the role. To exercise office, gentlemen had successfully to lay claim to a particular social role defined in terms of wider expectations and symbols of power. This constrained their freedom in the role. As office-holders they were engaged in an exercise in impression management, and their credibility in office rested to a large degree on the reception of their performance. (p. 27)

The description offered here of leadership as 'social roles demanding active representation' relates to an understanding of leadership as explicitly performance-based. In essence, nobles, courtiers, officials, and even monarchs were expected to exhibit the traditional behaviors, costumes, and discourse associated with their rank. Early moderns were so concerned with the integrity of such public performances that the government passed sumptuary laws designed to restrict apparel to specific classes and ranks

5. 'The principle,' explains Howard Pearce (1980), 'requires that the audience be considered part of the total context of the play' (p. 50). 
(Greenblatt 1980; Bailey 2001). ${ }^{6}$ Braddick and Walter (2001) suggest that these trappings of power were integral to the recognition of that power by those subordinate to it, a relationship that appears explicitly in Shakespeare's Henry $V$.

Goffman (1959) similarly describes performance as 'the activity of an individual which occurs during a period marked by his presence before a particular set of observers and which has some influence on the observers' (p. 22), emphasizing the interplay between the performer's actions and appearance, and the audience's reception of those actions. Discorfano (2003) refines this definition to be specific to leadership, stating that 'a leader can and often will actively manipulate his or her image and any surrounding drama to play on our imaginations' (p. 11). This methodology of image manipulation - also termed 'image building' or 'Impression Management' (Goffman 1959; Gardner and Avolio 1998) - was also a practice in which monarchs in state were expected to engage. This required not only the sovereign's performance, but also the audience's willingness to accept that performance as viable.

This relationship between leadership performance and follower (or audience) acceptance has also been remarked upon by Gardner and Avolio (1998), who suggest that charismatic leaders succeed by 'embodying the core values of the groups, organizations, or societies they represent, which promotes follower identification' (p. 34). Gardner and Avolio (1998) further suggest that 'Although followers primarily occupy the audience role' in this relationship, 'they are far more than passive targets for the leader [Impression Management]. Instead, they are active players who work with the leader to construct his or her charismatic identity' (p. 34). This aspect of 'working with' the leader, I argue, is the process of negotiation identified by Braddick and Walter (2001), and can be seen in the exchanges between Henry and his subjects, and is designed to draw attention to the parallel relationship between the audience-as-populace and their monarch.

The elements of performative negotiation that appear most prominently in Henry $\mathrm{V}$ occur in three specific contexts: the first, and most problematic, occurs when Henry threatens and engages in seemingly unjustified violence; in the second, Henry disguises himself as a commoner and confesses that 'the King but a man' (IV.i.102); and the last appears in Henry's legendary St Crispin's Day speech, given just prior to the battle of Agincourt. Together, these instances of performative negotiation help establish Henry's position as a martial, monarchical, and charismatic leader, but also reinforce the role of early modern drama in general, and Shakespeare in particular, in interrogating contemporary conceptions of sovereignty. While Edmondson (2000) remarks, 'Shakespeare then, invites us to view his portrait of the ideal leader as he sequentially reveals each dimension of his character' (p. 61), the image with which the audience is left at the play's conclusion is multivalent and paradoxical, unsettling rather than appeasing the ideology of providential monarchy.

6. Appropriate attire was crucial to the early modern understanding of social position both on and off stage, and continues to be a cultural index in an audience's recognition of an individual's leadership role (Goffman 1959, pp. 24-25). Accuracy of costume is important to the reception of theatrical performance, and the costumes of nobility that appeared on the early modern stage were often taken from the households of those who held similar public positions (MacIntyre 1992, p. 78). Concern with appropriate attire also included the often allegorical depictions of appropriate monarchical appearance. Elizabeth's formal gowns were costly and elaborate, and the dress in which she appeared in both pageants and portraits was specifically designed to evoke mythological and dynastic overtones (Strong 1987, pp. 37-38; Anglo 1992, p. 99). These concerns with apparel indicate that physical appearance was an index of an individual's status, but also of the intention and attitude the monarch intended to convey. 
The most vexing element of Henry's leadership appears in his demand for the surrender of the city of Harfleur, in which he threatens 'rapacious violence' (Deats 2004, p. 91), disrupting claims of ideal leadership:

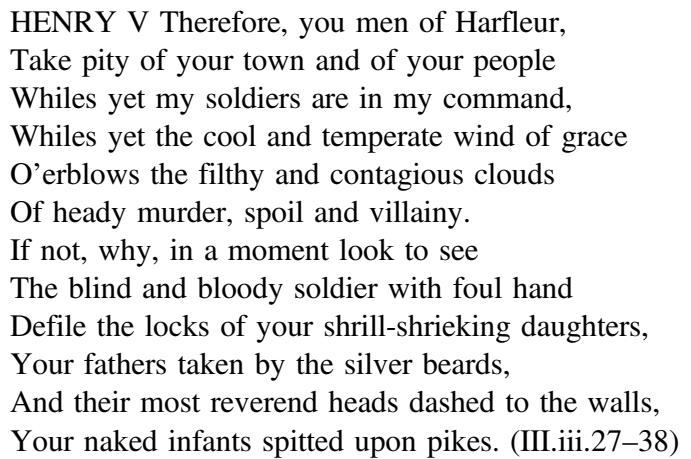

These threats are often ignored completely in leadership studies: for example, McCombs's (1992) description of Henry includes the assertion that 'One of Henry's personal credos is that: ... when lenity and cruelty play for a kingdom, the gentler gamester is the soonest winner' (p. 219). This sentiment is entirely absent from Henry's ultimatum, which is among the most vicious in Shakespeare's works. While Henry does not actually follow through with his threats - Harfleur immediately surrenders - the speech provides us with a moment of evidence for Henry's willingness either to commit atrocity or to use cruel falsehood to secure victory.

Deats (2004) suggests that this enumeration of atrocities indicates Henry's role as a 'virtuoso rhetorician whose words prove more puissant than swords as he topples a great city through the power of his oratory, thus preventing many deaths on both sides,' but that this rhetorical virtuosity is 'undermined by ... these very ringing words' (p. 91). In short, Henry's performative strategy reflects a despotic persona at odds with his later appearance as a fraternal figure concerned by the potential loss of his men's lives. Henry's willingness to commit questionable moral acts reappears when he commands the execution of the French prisoners: 'Then every soldier kill his prisoners! / Give the word through' (IV.vi.37-38). Deats (2004) suggests that his decision could have come 'for tactical reasons or for revenge' (p. 92) against the French for murdering the boys (servants and runners) left behind in the camp. However, while Henry reissues the order following his discovery of the French attack on the boys, his initial order comes before Flewellen announces the discovery of the slaughter. Henry excuses his unethical orders by placing blame post factum upon the French, just as he excuses his threats against Harfleur by forcing the Governor of the city to make the choice between surrender and violation.

Henry's actions are often justified as necessary to his success, yet if Shakespeare wanted to fully legitimize all of Henry's decisions, he would not complicate those decisions by having Henry attempt to reassign fault onto others. While some critics charge Henry with avoidance (Pittock 2009), Rothschild (1986) suggests that 'only a human being, would engage in such patent rationalization' (pp. 66-67), arguing that Henry's displacement of personal responsibility is an indicator of his laudable humanity. Shakespeare's construction of the king 'allows Henry himself to be troubled by those costs and responsive to the moral questions they raise. Thus it reveals him to be a finer model for a king than he had hitherto been allowed to be in the national consciousness' (ibid., p. 67). 
While Henry's 'humanity' may make him a more sympathetic figure - if Rothschild is to be believed - does it make him a better king?

On the most simplistic level of success, Henry's threats against Harfleur and his execution of French prisoners are practical decisions that contribute to his ultimate victory. On another level, such acts (or the threats thereof) undermine the pious and virtuous persona Henry seems to have cultivated in the play's early scenes. And yet it was important for an early modern monarch to be seen as capable of such extreme acts when compelled by necessity; when threatened by the Jesuit conspiracy to place Mary Queen of Scots on the English throne, Elizabeth ordered the torture of the conspirators and the execution of her royal cousin (Montrose 2006). Interestingly, the audience does not witness any internal trepidation from Henry with regard to these incidents, a lack that often diminishes the very sympathy Rothschild claims these acts produce. ${ }^{7}$ Nor does Henry seem to show regret or guilt over either his threats or the execution of the prisoners, perhaps because, as Pittock (2009) argues, he accepts 'no responsibility for his own actions' (p. 188). The only moments in which we see him 'humanized' appear when he is most concerned that blame will be laid at his feet for the death of the English, not the French.

This fear of personal accountability for his own followers prompts Henry to disguise himself as a commoner and speak with his soldiers on the eve of battle. He borrows Sir Thomas Erpingham's cloak and changes his language to match that of his men (prose, rather than the more traditional blank verse used by nobility). They perceive him not as a king, but as one of them - the difference in rank elided by Henry's 'common' performance. During this encounter, Henry admits trepidation about the upcoming battle, as he tells his men that kings are not significantly different from them in terms of needs and emotions: 'I think the King is but a man, as I am. ... Therefore when he sees reason of fears as we do, his fears, out of doubt, be of the same relish as ours are. Yet, in reason, no man should possess him with any appearance of fear, lest, he, by showing it, should dishearten the army' (IV.i.102-112). For Henry, the differentiation between himself as King and as Harry lies in performance; the king is required to eliminate 'any appearance of fear' for the sake of his followers, regardless of what he feels. Taunton (2001) suggests that the purpose behind Henry's foray into the camp is 'to appease his insecurity and vanity, to justify to himself a costly and difficult campaign, to assure himself of his rightful claim and above all to test out claims that God is on his side' (p. 177). However, her assertion that his motives are entirely selfish discounts his need to connect with his followers in order to better motivate both them and himself (McCombs 1992; Edmondson 2000; Rosendale 2004). In Henry's disguise, then, we likely find both self-serving and altruistic motives - a realistic rather than idealistic picture of sovereignty. Yet in this realism Shakespeare does not condemn Henry, specifically; rather, through the embodiment of an imperfect yet successful monarch we find a criticism of providential absolutism. Henry's faults - especially, as we will see, as highlighted by his encounter with Williams - do not make him a bad king, but they do defy claims of monarchical infallibility and complete divine authorization in favor of the subject-located legitimation found in participatory limited monarchy.

Confronting the disguised king (whom he does not recognize), Williams insists that 'Now if these men do not die well it will be a black matter for the King, that led them

7. It is unclear whether an early modern audience would be as appalled by Henry's actions as a modern one; period accounts seem to indicate similar sympathetic responses to other events, such as sadness at the death of Talbot in 1 Henry VI (Walsh 2007, p. 58). 
to it, who to disobey were against all proportion of subjection' (IV.i.143-146). Rather than assuaging his fears, Henry learns that his men hold him fully accountable for their deaths - and their souls:

HENRY V Upon the King! 'Let us our lives, our souls,

Our debts, our careful wives,

Our children and our sins lay on the King!'

We must bear all. $\mathrm{O}$ hard condition,

Twin-born with greatness, subject to the breath

Of every fool whose sense no more can feel

But his own wringing! What infinite heart's ease

Must kings neglect that private men enjoy!

And what have kings that privates have not too,

Save ceremony, save general ceremony? (IV.i.227-236)

Williams's accusations call both Henry's and the audience's attention to the duality of leadership: Henry may be akin to common men, but he is also more than they by virtue of his performative leadership role. Henry's reminder to the playhouse audience of his own inadequacies are placed in opposition to his willingness to accept his responsibilities as king, to performatively negotiate with his subjects for sovereign authority, and to fulfill his obligations as a martial, sovereign, and charismatic leader.

Shakespeare returns to this scene following the battle when Williams challenges Fluellen. During Henry's initial conversation with Williams, he and the soldier exchange gloves as tokens of their quarrel. Henry later gives Williams's glove to Flewellen, and when Williams sees it, he issues a challenge to the confused Welshman. Henry intercedes, and reveals himself: 'Twas I indeed thou promised'st to strike, / And thou hast given me most bitter terms' (IV.viii.42-43). Williams, however, refuses to continue on the grounds that a disguised Henry was not, in fact, the king:

WILLIAMS Your majesty came not like your self: you appeared to me but as a common man witness the night, your garments, your lowliness; and what your highness suffered under that shape, I beseech you take it for your own fault and not mine, for had you been as I took you for, I made no offence; therefore I beseech your highness pardon me. (IV.viii.51-57)

By rewarding Williams with 'an honour' and 'crowns' (IV.viii.60 and 58) rather than punishing him, Shakespeare confirms the soldier's understanding of monarchy as performance: when Henry is not actively playing the role of king, he ceases to be the king (Bezio 2010, pp. 15-16). It is important for Henry's negotiation of power that he specifically conform to the expectations of followers such as Williams, as Black (1975) explains: 'What they would have the King be is linked to their dreams, and their dreams are of history, of chivalry, and of epic. Henry knows what he is doing, so does Shakespeare' (p. 13). Such an ideology explicitly contradicts claims of providential absolutism, again reinforcing an interpretation of Henry $V$ in which Henry's success relies on performative negotiation rather than providence or primogeniture.

Such a reading is, finally, positively enforced through the depiction of Henry's famous rallying of his troops. Henry's St Crispin's Day speech, given the morning following his first encounter with Williams, is perhaps the most famous speech in Henry $V$, and one of the most notable - and oft-quoted - in Shakespeare. The speech is worth reproducing at length:

HENRY V This story shall the good man teach his son,

And Crispin Crispian shall ne'er go by

From this day to the ending of the world 
But we in it shall be remembered,

We few, we happy few, we band of brothers.

For he today that sheds his blood with me

Shall be my brother; be he ne'er so vile,

This day shall gentle his condition.

And gentlemen in England now abed

Shall think themselves accursed they were not here,

And hold their manhoods cheap whiles any speaks

That fought with us upon Saint Crispin's day. (IV.iii.56-67)

Here, Henry's rhetorical facility is displayed at its utmost. The structure and syntax of Henry's speech are designed for public oratory:

its movement from the King's honor to his people's; its crescendo variations on St. Crispin's day, reaching their climax in the last line; its rhythmic patterns expanding repeatedly from broken lines to flowing periods in each section and concluding climactically in the coda that begins 'We happy few'; its language constantly addressed to the pleasures, worries, and aspirations of an audience of citizens. ... We recognize it as a performance; we share the strain of the King's greatness, the necessary effort of his image-projecting. (Rabkin 1977, p. 286)

Discorfano (2003) remarks that in a 1994 theatrical production the speech was delivered to only a few nobles, a decision which undermined its intended rhetorical power: 'The point was to emphasize Henry's humanness, and our own - and history's penchant for construing things in a way that is favorable to our own needs. Sitting in the theater, I found myself longing for that rallying speech, wanting that moment of leadership' (p. 11). Without proclamatory rhetoric, Henry's speech fails to persuade his audience of his efficacy as a martial or political leader, just as he failed to persuade Williams during their night-encounter. The circumstances by the literal light of day are no different for Henry than they were when he confessed his fears to the playhouse audience, however Henry is now performing to an onstage audience as well, and must present an appropriate persona.

In aligning himself with all levels of the populace, Henry returns to the point he made earlier in a private context: the king and the common man are one and the same. He 'attempts to win consent' (Tebbets 1990, p. 11) for the impending battle from both nobles and commons. However, here Henry is successful in convincing both his and Shakespeare's auditors because instead of lowering himself, as in his conversation with Williams, he raises up his followers to be 'my brother' by virtue of the shared combat that 'shall gentle his condition.' Elevation is more discursively successful than diminution, and permits rhetorical egalitarianism that does not give up the importance of honor and nobility while equating Henry with his followers. Performed both metaphorically and literally to a socially multifaceted audience - on stage, it is addressed to nobles and commons, and its performances similarly target nobility, royalty, and commons at Court and public performances - the speech enables the player (as the vehicle for Shakespeare's language) to claim equality not only with nobles and commons, but even with the Queen herself when given at Court. The content of Henry's speech, too, identifies him with Elizabeth, as it echoes her address to the English forces at Tilbury, facing the Spanish Armada (Bezio 2013, p. 40). ${ }^{8}$ Henry's

8. Elizabeth's speech is quoted by Dr Lionel Sharp as follows: 'I am come among you at this time but for my recreation and pleasure, being resolved in the midst and heat of battle to live and die amongst you all' (Marcus et al. 2000, p. 325). 
discourse makes an explicit claim for the importance of performance - and rhetoric to the construction of leadership roles and relationships in early modern England; by specifically linking Henry and Elizabeth, Shakespeare is able to praise Elizabeth's selfconscious theatricality, but is also able to express anxiety about her impending unnamed heir.

Because of Henry, the English are successful at Agincourt, losing only 29 to over 10000 French. As the play moves toward its conclusion, we see Henry put aside martial responsibilities and successfully play both the savvy politician and the lover, securing French surrender and the hand of Princess Katherine. A consummate leader, Henry is capable of assuming the roles demanded of him, adapting his attitude, language, and personation to each situation as required (Tennenhouse 1986). Yet Henry V does not end on a triumphant chord.

Although, as the play itself acknowledges, Henry's life and death have already passed, the epilogue's reminder of the failure of English monarchy reveals the intense anxiety present at the close of Elizabeth's reign:

CHORUS Fortune made his sword

By which the world's best garden he achieved,

And of it left his son imperial lord.

Henry the Sixth, in infant bands crowned King

Of France and England, did this king succeed,

Whose state so many had the managing

That they lost France and made his England bleed. (Epilogue.6-12)

The epilogue refers here to the events of Shakespeare's First Tetralogy, during which Henry VI loses control of France, causes the War of the Roses, and is deposed and executed, followed by the tyrannical reign of Richard III. At the conclusion of Richard III, however, is the arrival of Henry VII, founder of the Tudor dynasty (Tillyard 1946). The promise of security that seems implicit in Henry VII's appearance is fractured by the political circumstances of 1599 - Henry VII's granddaughter, Elizabeth, is an aging monarch with no heir, and England faces yet another potential civil war. And while Elizabeth - like the image of Henry created by Shakespeare - is a consummate performer (Marcus et al. 2000), the charismatic leadership produced by performative negotiation only endures so long as the performer is alive to enact it (Parolin 2009; Bezio 2013).

What we find in the historical sequences of the First Tetralogy and the Henriad, concluding with Henry $V$, is an argument against the absolutist ideology that can lead to the loss of rights, fragmentation, tyranny, and ultimately civil war. In Henry, Shakespeare presents a kind of realistic ideal: a flawed king who nevertheless is able to achieve success because he does not rely on a presumption of absolute authority. Henry seeks justification for every action he takes throughout the play: from the bishops to begin the war, from his enemies for their defeat, from the French king for his alliance with Katherine, from his soldiers for their sacrifice, and even from God for his eventual victory. These acts of performative negotiation - both private and public - ensure his success and provide an exemplum to England's future monarch. The epilogue follows this illustration with a warning of what could ensue - rebellion, civil war, and regicide - if this example is not followed.

Shakespeare does not give us or his audience a satisfactory answer to the question of the succession. As a playwright in the service of an Elizabethan courtier, he was undoubtedly aware of the debates concerning the future of the English throne, despite 
the illegality of such conversations (Montrose 2006). It is not Shakespeare's purpose in Henry $V$, however, to argue for a specific candidate. ${ }^{9}$ Rather, Henry $V$ acts as a eulogy for the Tudor dynasty and an expression of hope and fear about England's future. For while the play's focus on performativity ultimately praises Elizabeth's successful negotiation with her subjects, the epilogue (and the earlier plays to which it alludes) reminds its audience that not all monarchs are successful - or as willing to accept limitations placed on their authority.

9. Some critics read an endorsement of the Earl of Essex into the Choric interlude between the fourth and fifth acts. The problem of Essex - to whom Shakespeare compares Henry returning to London as being like 'the General of our gracious Empress' (V.0.30) returning victorious from Ireland (which he, in fact, did not, although Shakespeare would not have known that when writing the play) - is that the link between Elizabeth's General and Henry is imperfect and even more problematic than the character of Henry himself. Albright (1928) notes that 'Essex was at this time definitely out of favor with Elizabeth and a group of powerful courtiers, and was being spied upon in his Irish enterprise' (p. 728). She continues, suggesting that 'Shakespeare was definitely taking sides' (ibid., p. 728), but does not actually state which side she believes the author falls on, although she does explain that Shakespeare's patron, Henry Wriothesley, the Earl of Southhampton, was an ally of Essex's. While this is compelling, all it really indicates is that Shakespeare wished to please his patron - or, at least, not to displease him.

Additional evidence Albright (1928) supplies for the parallel between Henry and Essex lies in his lineage; while it is true that both Essex and Henry were able to claim descent from Edward III, so was Elizabeth herself, as could a wide variety of noble lines in court in 1599, including James VI of Scotland, whose claim was also through the female line (pp. 738-739). Furthermore, Albright (1928) offers the suggestion that the alliance between Henry and Katherine at the play's conclusion is an allusion to Essex's desire to ally with France (pp. 748-749); yet within the play itself, the mockery made of the French in general hardly seems to indicate sympathy with such a sentiment. Ultimately, though, even Albright (1928) comes to the conclusion that "Whether "England for the English" meant, to Shakespeare, as it did to some of his countrymen, a preference for Essex as a prospective ruler, rather than the feared domination by Spain, Scotland, or even France, it is difficult to say,' although she does note that 'it is clear that he has definitely likened Essex to the very best and most patriotic king' (p. 753) of the history plays.

Certainly, as Patterson (1989) notes, it is important to acknowledge that Shakespeare was rooting history within his contemporary context through the mention of Essex, but that does not inherently mean that Essex himself should be unequivocally mapped onto Henry as idealized king (p. 71). Parolin (2009) observes, importantly for our purposes, that Henry is also likened to Caesar, the legendary builder of the Tower of London, but also the tyrant whose death was staged by the Lord Chamberlain's Men, along with Henry V, in 1599 (p. 44). It seems unlikely that Caesar, himself a military hero, would be used as a support for Essex's monarchical ambitions were Shakespeare wholeheartedly intending to support him. Rather, it seems that a combination of these motives is the most likely conclusion: Shakespeare, whose patron supported Essex, would be disinclined to openly criticize Essex, but, given the context of the Elizabethan succession crisis, neither would he be likely to fully endorse the Earl. Instead, the depiction we get of an already paradoxical and problematic king in Henry is further complicated by his alignment to general (Essex), tyrant (Caesar), and Queen. This indicates to me that Henry embodies both the hopes and the fears about the future unknown monarch of England, who - while unknown - has the potential to fulfill any of the characteristics contained in Henry, to either the great benefit or the great detriment of England. 


\section{REFERENCES}

Albright, E.M. (1928), 'The Folio Version of Henry V in Relation to Shakespeare's Times,' PMLA, 43 (3), 722-756.

Anglo, S. (1992), Images of Tudor Kingship, London: B.A. Seaby.

Axton, M. (1977), The Queen's Two Bodies: Drama and the Elizabethan Succession, London: Royal Historical Society.

Bailey, A. (2001), '"Monstrous Manner": Style and the Early Modern Theater,' Criticism, 43 (3), 249-284.

Baumer, F.L.V. (1966), The Early Tudor Theory of Kingship, New York: Russell \& Russell.

Bernheimer, R. (1956), 'Theatrum Mundi,' The Art Bulletin, 38 (4), 225-247.

Bezio, K. (2010), 'Politics and Play: The National Stage and the Player King in Shakespeare's Henry $V$ and Macbeth', Quidditas, 31, 10-21.

Bezio, K. (2013), 'Drama and Demigods: Kingship and Charisma in Shakespeare's England,' Religions, 4 (1), 30-50.

Birdsall, P. (1967), “'Non Obstante”: A Study of the Dispensing Power of English Kings,' in C. Wittke (ed.), Essays in History and Political Theory in Honor of Charles Howard McIlwain, New York: Russell \& Russell, pp. 37-76.

Black, J. (1975), 'Shakespeare's Henry V and the Dreams of History,' English Studies in Canada, 1, 13-30.

Braddick, M.J. and J.C. Walter (2001), 'Introduction. Grids of Power: Order, Hierarchy and Subordination in Early Modern Society,' in M.J. Braddick and J.C. Walter (eds), Negotiating Power in Early Modern Society: Order, Hierarchy and Subordination in Britain and Ireland, Cambridge, UK: Cambridge University Press, pp. 1-42.

Cohn, R. (1967), “'Theatrum Mundi” and Contemporary Theater,' Comparative Drama, 1 (1), 28-35.

Craig, H. (1912), 'Introduction,' in The Tragedy of Richard the Second, New York: Macmillan.

Cronin, T.E. and M.A. Genovese (2012), Leadership Matters: Unleashing the Power of Paradox, Boulder: Paradigm Publishers.

Deats, S.M. (2004), 'Henry V at War: Christian King or Model Machiavel,' in S.M. Deats, L.T. Lenker and M.G. Perry (eds), War and Words: Horror and Heroism in the Literature of Warfare, Lanham: Lexington Books, pp. 83-101.

Discorfano, S. (2003), 'The Creation of a Leader in Shakespeare's "Henry V",' Leadership in Action, 23 (4), 11.

Eccleshall, R. (1978), Order and Reason in Politics: Theories of Absolute and Limited Monarchy in Early Modern England, Oxford: Oxford University Press.

Edmondson, H.T. III (2000), 'Shakespeare's Henry V and the Act of Ethical Reflection,' in H.T. Edmondson III (ed), The Moral of the Story: Literature and Public Ethics, Lanham, MD: Lexington Books, pp. 59-74.

Elshtain, J.B. (2008), Sovereignty: God, State, and Self, New York: Basic Books.

Gardner, W.L. and B.J. Avolio (1998), 'The Charismatic Relationship: A Dramaturgical Perspective,' The Academy of Management Review, 23 (1), 32-58.

Goffman, E. (1959), The Presentation of Self in Everyday Life, New York: Anchor Books.

Greenblatt, S. (1980), Renaissance Self-Fashioning: From More to Shakespeare, Chicago: The University of Chicago Press.

Gurr, A. (1980), The Shakespearean Stage, 1574-1642, Cambridge, UK: Cambridge University Press.

Hawkins, H.B. (1966), “'All the World's a Stage”: Some Illustrations of the Theatrum Mundi,' Shakespeare Quarterly, 17 (2), 174-178.

Hazlitt, W. (1920), 'Henry V,'Characters of Shakespeare's Plays and Lectures on the English Poets, London: Macmillan, pp. 125-132. Available at: http://books.google.com/books?id= lfDPAAAAMAAJ\&printsec=frontcover \&dq=hazlitt+characters+in+shakespeare \&hl=en \& $\mathrm{sa}=\mathrm{X} \&$ ei=npu6T4LFBejH6AH15tmVBg\&ved=0CDcQ6AEwAA\#v=onepage \&q=hazlitt $\% 20$ characters $\% 20 \mathrm{in} \% 20$ shakespeare $\& \mathrm{f}=$ false. 
MacIntyre, J. (1992), Costumes and Scripts in the Elizabethan Theatres, Edmonton: The University of Alberta Press.

Marcus, L.S., J. Mueller and M.B. Rose (eds) (2000), Elizabeth I: Collected Works, Chicago: University of Chicago Press.

McCombs, G.M. (1992), "'Once more unto the breach, dear friends": Shakespeare's Henry V as a Primer for Leaders,' The Journal of Academic Librarianship, 18 (3), 218-220.

McEachern, C. (1994), 'Henry V and the Paradox of the Body Politic,' Shakespeare Quarterly, 45 (1), 33-56.

McIlwain, C.H. (ed.) (1918), The Political Works of James I, Cambridge, MA: Harvard University Press.

Montrose, L. (1996), 'Shakespeare, the Stage, and the State,' SubStance, 25 (2), $46-67$.

Montrose, L. (2006), The Subject of Elizabeth: Authority, Gender, and Representation, Chicago: The University of Chicago Press.

Myers, H.A. (1982), Medieval Kingship, Chicago: Nelson-Hall.

Nehls, K. (2012), 'Leadership Education: The Power of Storytelling,' in J.D. Barbour (ed.), Leading in Complex Worlds, San Francisco: Jossey-Bass, pp. 63-77.

Nenner, H. (1977), By Colour of Law: Legal Culture and Constitutional Politics in England, 1660-1689, Chicago: The University of Chicago Press.

Parolin, P. (2009), 'Figuring the King in Henry V: Political Rhetoric and the Limits of Performance,' Journal of the Wooden O Symposium, 9, 43-60.

Patterson, A. (1989), Shakespeare and the Popular Voice, Cambridge, UK: Basil Blackwell.

Pearce, H.D. (1980), 'A Phenomenological Approach to the Theatrum Mundi Metaphor,' PMLA, 95 (1), 42-57.

Pittock, M. (2009), 'The Problem of Henry V', Neophilogus, 93, 175-190.

Pye, C. (1990), The Regal Phantasm: Shakespeare and the Politics Of Spectacle, Routledge: London.

Rabkin, N. (1977), 'Rabbits, Ducks, and Henry V,' Shakespeare Quarterly, 28 (3), 279-296.

Rackin, P. (1990), Stages of History: Shakespeare's English Chronicles, Ithaca: Cornell University Press.

Rosendale, T. (2004), 'Sacral and Sacramental Kingship in the Lancastrian Tetralogy,' in D. Taylor and D.N. Beauregard (eds), Shakespeare and the Culture of Christianity in Early Modern England, New York: Fordham University Press, pp. 121-140.

Rothschild, H.B. Jr (1986), 'The Conqueror-Hero, the Besieged City, and the Development of an Elizabethan Protagonist,' South Central Review, 3 (4), 54-77.

Shakespeare, W. (1995), King Henry V, T.W. Craik (ed.), London: Methuen, the Arden Shakespeare, Third Series.

Shapiro, J. (2005), 1599: A Year in the Life of William Shakespeare, New York: Harper Collins.

Shushok, F. Jr and S.H. Moore (2010), 'Reading, Study, and Discussion of the "Great Texts" of Literature, Philosophy, and Politics as a Complement to Contemporary Leadership Education Literature,' Journal of Leadership Studies, 3 (4), 71-80.

Smith, L.B. (1996), This Realm of England: 1399-1688, Vol. 2, 7th edn, Lexington, MA: D.C. Heath and Company.

Sommerville, J.P. (1999), Royalists and Patriots: Politics and Ideology in England 1603-1640, 2nd edn, London: Longman.

Starkey, D. (1986), 'Which Age of Reform?,' in C. Coleman and D. Starkey (eds), Revolution Reassessed: Revisions in the History of Tudor Government and Administration, Oxford: Clarendon Press, pp. 13-27.

Starkey, D. (2006), Crown and Country: The Kings and Queens of England: A History, London: HarperPress.

Strohm, P. (1996), 'The Trouble with Richard: The Reburial of Richard II and Lancastrian Symbolic Strategy,' Speculum, 71 (1), 87-111.

Strong, R. (1987), Gloriana: The Portraits of Queen Elizabeth I, New York: Thames and Hudson. 
58 Leadership and the Humanities, Vol. 1 No. 1

Taunton, N. (2001), 1590s Drama and Militarism: Portrayals of War in Marlowe, Chapman, and Shakespeare's Henry V, Aldershot, UK: Ashgate.

Tebbetts, T.L. (1990), 'Shakespeare's Henry V: Politics and the Family,' South Central Review, 7 (1), 8-19.

Tennenhouse, L. (1986), Power on Display: The Politics of Shakespeare's Genres, New York: Methuen.

Tillyard, E.M.W. (1946), Shakespeare's History Plays, New York: Macmillan.

Walsh, B. (2007), 'Theatrical Temporality and Historical Consciousness in the Famous Victories of Henry V,' Theatre Journal, 59 (1), 57-73.

Weimann, R. (1978), Shakespeare and the Popular Tradition in the Theater: Studies in the Social Dimension of Dramatic Form and Function, R. Schwartz (ed.), Baltimore: The Johns Hopkins University Press (Original work published 1967, in German.).

Wills, G. (1994), Certain Trumpets: The Nature of Leadership, New York: Simon \& Schuster. 